\title{
Witchcraft and Witch-Hunting : Perceptions, Interventions and Resolution
}

\author{
${ }^{1}$ Meena Kumari , ${ }^{2}$ Shamsher Alam
}

${ }^{1}$ Doctoral Scholar, Department of Contemporary and Tribal Customary Law,Central University of Jharkhand, India.

${ }^{2}$ Assistant Professor, Department of Contemporary and Tribal Customary Law, Central University of Jharkhand, India.

\section{ABSTRACT}

The practices of witchcraft and witch-hunting, despite cultural and regional differentiations, have been able to maintain its global presence. Ubiquitously traced in several countries, the convention of accusing and killing people, especially women, on charges of practicing witchcraft is prevalent in India as well. Resting upon empirical data, we attempt to put forth an overview about the nature and character of these practices from the perspective of community members residing in the province which records the highest number of witchcraft related killings in India, i.e. Jharkhand. An evaluation of reasons, as well as policy interventions in place for preventing such practices in the region have been delineated in the paper. Simultaneously, fortified within the emancipatory framework of research, steps for contending and combating this protruding concern have also been advanced. Putting compendiously, the overall quintessence of this endeavour is to put forward ways to bring about the desired social change, wherein such superstition driven customs take an adieu.

Keywords :

Emancipation, Jharkhand, Superstitious Killing, Social Change, Tribals, Witchcraft, Witch Hunting.

\section{INTRODUCTION}

Natural calamities, bad weather, diseases, epidemics, and deaths have always bothered human beings. All these have paved the path for faith in supernatural powers and coming up of religion and magic (Frazer, 1998). In religion, powers are revered and pleased for preventing negative circumstances, whereas magic aims at gaining control over such powers for causing benevolent or malevolent influences (Frazer, 2013). Witchcraft as a form of malevolent magic, has established its presence for negative situations across the globe (Hutton, 2017). Owing to its perceived negative intents, witchcraft is looked upon with pessimism (Bosker, 2020). People suspected to be allied with this craft are often accused of causing detrimental impacts (Mabefam \& Appau, 2020) and are often trialled, branded, hounded, flogged and even ruthlessly murdered (Purohit, 2020). This practice is witchhunting.

Witch hunting is reported from almost all existent communities of the world since times immemorial (Behringer, 1999). It has been predominant in India as well, particularly among the rural and isolated precincts, which also happens to be the dwelling place of tribals (Saletore, 1981). The latest report of NCRB (National Crime Records Bureau, a unit functioning under the Ministry of Home Affairs, Govt. of India) mentions that 2694 people were hunted in India between 2001 and 2018, on alleged charges of practicing witchcraft.

\begin{tabular}{|c|c|c|c|c|c|c|c|c|c|}
\hline Year & Jharkhand & Odisha & $\begin{array}{c}\text { Andhra } \\
\text { Pradesh } \\
\text { and } \\
\text { Telangana }\end{array}$ & $\begin{array}{c}\text { Madhya } \\
\text { Pradesh }\end{array}$ & Haryana & Chhattisgarh & Bihar & $\begin{array}{c}\text { Other } \\
\text { States }\end{array}$ & India \\
\hline 2018 & 18 & 05 & 11 & 10 & 03 & 08 & 00 & 07 & 62 \\
\hline 2017 & 19 & 09 & 05 & 13 & 00 & 06 & 01 & 20 & 73 \\
\hline 2016 & 27 & 24 & 19 & 19 & 02 & 17 & 00 & 26 & 134 \\
\hline 2015 & 32 & 26 & 15 & 20 & 00 & 13 & 02 & 27 & 135 \\
\hline 2014 & 47 & 32 & 02 & 24 & 00 & 16 & 06 & 29 & 156 \\
\hline 2013 & 54 & 24 & 15 & 11 & 00 & 07 & 00 & 49 & 160 \\
\hline 2012 & 26 & 32 & 24 & 10 & 00 & 08 & 13 & 06 & 119 \\
\hline 2011 & 36 & 39 & 28 & 15 & 05 & 17 & 00 & 100 & 240 \\
\hline 2010 & 15 & 31 & 26 & 18 & 57 & 08 & 02 & 21 & 178 \\
\hline 2009 & 37 & 28 & 27 & 23 & 30 & 06 & 02 & 21 & 174 \\
\hline 2008 & 52 & 23 & 23 & 16 & 25 & 15 & 00 & 21 & 175 \\
\hline 2007 & 50 & 28 & 33 & 14 & 30 & 08 & 00 & 14 & 177 \\
\hline 2006 & 29 & 36 & 26 & 13 & 34 & 10 & 11 & 27 & 186 \\
\hline
\end{tabular}




\begin{tabular}{|l|l|l|l|l|l|l|l|l|l|}
\hline 2005 & 26 & 25 & 75 & 13 & 28 & 09 & 01 & 20 & 197 \\
\hline 2004 & 26 & 22 & 24 & 14 & 00 & 11 & 00 & 14 & 111 \\
\hline 2003 & 19 & 26 & 37 & 26 & 00 & 09 & 00 & 23 & 140 \\
\hline 2002 & 26 & 39 & 23 & 24 & 00 & 04 & 01 & 34 & 151 \\
\hline 2001 & 21 & 30 & 20 & 13 & 00 & 14 & 01 & 27 & 126 \\
\hline TOTAL & $\mathbf{5 6 0}$ & $\mathbf{4 7 9}$ & $\mathbf{4 3 3}$ & $\mathbf{2 9 6}$ & $\mathbf{2 1 4}$ & $\mathbf{1 8 6}$ & $\mathbf{4 0}$ & $\mathbf{4 8 6}$ & $\mathbf{2 6 9 4}$ \\
\hline
\end{tabular}

Witchcraft Killings in India (2001-2018) (Source : NCRB, Govt. of India)

The non-reported cases, and those involving human right violations but not leading to execution, are however completely left out in these figures (Mehra \& Agrawal, 2016). Dissection of these numbers reveal that such incidences are more protuberant in provinces of Haryana, Rajasthan, Gujarat, Maharashtra, Madhya Pradesh, Uttar Pradesh, Chhattisgarh, West Bengal, Jharkhand, Odisha, Bihar and Assam (Singh, 2011). Among them, more than one-fifth of the cases are from Jharkhand (Srivastava, 2015).

These varied forms of violence involving gruesome acts of maltreatment and eventually murdering of people, are among the least acceptable standard of behaviour in any human community. It infringes a whole range of regional, national as well as international laws. Furthermore, agencies working for preventing witch-hunting have been relatively less successful in preventing such acts. The number of cases

\section{REVIEW OF LITERATURE}

Etymologically the term 'witchcraft' is a compound of two words 'wicce' and 'cræft' wherein the word 'wicce' derives its origin from the old English word 'wicca' meaning 'witch' and 'cræft' denotes 'skill or ability' (Dilts, 2015). It thus infers to the practice of, and belief in, magical skills and abilities which are believed to influence the mind, body, or property of others, in a malicious manner. Malinowski (1944) acknowledged witchcraft as a pragmatic and logical means for overcoming the uncertainties of human life and held it to be rational, which comes to aid when things could not be explicated through logical thinking (Levack, 2013) or whenever religion was assumed to be insufficient in coping difficult situations (Oliver, 1989). People associated with witchcraft are often accused of causing detrimental events and are thereafter subjected to mass torture and outrage, often leading to adverse inhuman treatments, comprising of ostracizing, banishment, hounding, rape, burning alive and even registered with police under various sections of existing laws, judgments delivered by courts, initiatives by governmental and non-governmental agencies, and overall policies of government for countering witchcraft and witch-hunting, have made very insignificant contribution towards changing the mindset of people for banishing this practice, due to which it still continues to exist in Jharkhand (Purohit, 2020; Singh, 2016). Also, studies conducted by scholars for tracing socio-cultural and associated facets accountable for pervasive prevalence of this phenomenon, especially among the tribals of the state, have been very scarce. Henceforth, there stands a pertinent compulsion to have an enquiry for understanding the perspective of tribals on witchcraft and witch-hunting, including its intersection with existing laws in force, and prevailing policies in action for thinking through, with the people, about ameliorative and emancipatory process for combating this inhuman practice.

execution (Singh, 2011). This practice of eliminating the practitioners of witchcraft has been pervasively customary in almost all societies of the globe and has led to killing of huge number of people on alleged charges of practicing the craft (Allen \& Reid, 2015). Geographically, witchcraft violence has global presence as evidenced by documentations, paintings and other testimonies emanating from African, American, European, Middle East, South Asian and Island nations (Alam \& Raj, 2017).

Witch-hunting is pervasive in India as well. Reports indicate that 2,694 people were assassinated on charges of practicing witchcraft between 2000 and 2018 (NCRB, 2018). These are statistics which have been logged in, however the unrecorded ones are anticipated to be far more than this number (Mehra \& Agarwal, 2016). More women have faced implications of witchcraft accusations and hunting than males, clearly inferring towards its gendered nature (Kingsley \& Clement, 2014). It has acted as a form of terrorism through which males have frightened, dominated and 
controlled females (Goodare, 2016) and have also utilized it to keep women 'in their place' by means of rape, domestic violence, sexual harassment, and other acts of brutality (Stewart \& Strathern, 2004). However, there have been several instances of assassination of males and children as well on charges of practicing witchcraft (Amnesty International, 2010).

Although witch-hunting is very context dependent, but still there are certain commonly observed factors which often instigate it. Among them, caste conflict, class-differences, gender strife, lack of critical thinking, poverty, ill health, and anything worthy of attracting envy - are some of the common reasons behind witchhunting (Mallick, 2008; Summers, 2000). These circumstances prompt blaming and scapegoating, and this is how it has evolved as a way-out for coping with uncertainties of human existence (Sundar, 2001). For combating witch-hunting, legal recourses have been put in place. However, they should not be taken as sufficient response to problems originating in society due to evil practices, irrationality or superstition (Mehra \& Agarwal, 2016). Such legislations cannot end superstition, provide redressal to victims or inject scientific approach and rationality in the community. They also do not take into account the conditions under which such practices flourish, the gaps in existing laws, the mode of reporting of cases, the investigation carried after reporting, and emergent needs of victims and survivors. Hence, a more social approach needs to be adopted, than just being strictly legal (Mehra \& Agarwal, 2016).

A comprehensive analysis of conducted studies leads to identification of certain gaps which have been relatively less touched upon previously. Amongst them, the ones which come out predominantly include dearth of studies relating to perception and conviction of tribals concerning witch-hunting and witchcraft. Also, a circumscribing analysis of factors accountable for sustained continuation of witch-hunting has not been attempted in earlier researches. Another void is the limited number of emancipatory researches pertaining to forwarding of inclusive and recuperative measures for combating witch-hunting. Against this backdrop, the current paper attempts to comprehend the perspectives of tribals concerning witchcraft and witch-hunting, including its intersection with existing laws, prevailing policies and education, for suggesting ways for its amelioration.

\section{OBJECTIVES AND ADOPTED METHODOLOGY}

The current study was carried out with the objectives of : (a) bringing in light the nature and character of witchcraft and witch-hunting, (b) assessing reasons for rampant protuberance of such practice among the tribals, and (c) forwarding ways through which witchcraft and witch-hunting could be truncated. For this, phenomenological and emancipatory methodologies formed the kernel of this paper. Due to preponderance of witch-hunting cases in Jharkhand, it was selected as the study area. Here witchcraft killings are mostly reported from tribal dominated zones. In view of this, Ranchi district, which has the highest tribal population among all districts of the state, was sampled as the target area for this research. Ranchi district has two sub-divisions, namely Bundu and Ranchi. For making the study representative in nature, two villages from each of these sub-divisions were sampled for study. In the study area, respondents were largely selected through purposive snowball sampling. Primarily, the elected village heads (locally designated as mukhiya) were consulted in each village. After explaining them about the objectives of study and convincing them for their support, information about people who were involved in treatment of supernatural ailments, were gathered. They also facilitated in getting nodal people who assisted in providing information about the village, its geography, instances of witchcraft allegations which had occurred in past, and access to other key respondents who were intimately or distantly related to such occurrences.

For collection of primary data, field work was conducted between March 2019 and June 2020. Initially key informants were identified and thereafter, rapport was established. After a brief baseline study of sampled villages, data relating to research were gathered by means of quasi participant observation, schedule and case study techniques. A total of 113 respondents comprising of youth, village elders, witch-doctors, elected representatives and alleged witches, were interviewed. Questions were largely open-ended where respondents were allowed to speak at length for congregating factual as well as contextual information. 
Genealogical table, photography and audio recording tools were utilized for effective capturing of information. Secondary data relating to the study were gathered from NCRB reports, court cases, and other data sources including online and offline newspaper reports, relevant websites, published reports, media clippings, online journals, books, circulars, office orders and publications of NGOs.

Once collection of data culminated, all recorded interviews were transcribed from local languages (Hindi, Sadri, Nagpuri and Khortha) to English, and thereafter broad themes and sub-themes were identified. Overlapping themes, commonalities and divergences were segregated through colour-based coding. Thereafter, findings were analyzed to arrive at segments expounding in detail about the research. The findings arrived at, were then suitably placed under different headings and sub-headings for easy discernment and comprehension. During the study, ethical concerns especially those relating to field-based researches, were diligently taken care off. Informed consent was sought before gathering of data. Participation of informants was purely confidential and voluntary. If at any point during data gathering, informants did not feel comfortable, they had the liberty to opt-out. Also, anonymity was maintained for all research participants.

\section{SALIENT FINDINGS}

Ethnographic study in the four sampled villages provided intricate understanding of witchcraft and witch-hunting in the region. Largely leaning towards malevolent form of magic, witchcraft plays its role in everyday activities of community residents. It forms an important part of the vast background of socio-religious activities prevalent in the area, the influence of which is evidently visible on the customary practices, laws, morals and etiquettes of people. The prominent findings have been delineated in the following sub-sections, wherein nuances pertaining to nature and character of witchcraft and witch-hunting, reasons for its protuberance, and interventions in existence for preventing such practices have been rendered.

\subsection{Nature and Character of Witcheraft and Witch- Hunting}

Witchcraft, colloquially famous as dayanbisahi in the study area, is something which haunts and scares people in the entire region. According to resident tribals, it infers to the practice of invoking diabolical occult powers for causing unfortunate happenings. Faith in the craft is so deep-seated and entwined that existence of witches, their craft, bewitchment and super natural happenings is not at all a matter of surprise or wonderment in the community. People staunchly trust that it has existed, and will continue to exist, just as existence of God and evil-powers in this world. According to them, everything happening in this world is controlled by cosmic powers and it is the intervention and disturbances caused to these powers, through the action of witchcraft, that they are deviated from their natural course, leading to manifestation/s in the form of uninvited events. These convictions also bestow people with moral justification for initiating preventive and corrective measures for safeguarding themselves from malevolent influences of witchcraft like performing religious rituals, pleasing supernatural powers, offering sacrifices, conducting ordeals, and even killing alleged individuals accountable for such deleterious happenings.

The blame for unfortunate happenings in the tribal cosmos is often levelled upon witches, colloquially referred as dayan or bisahi. Faith in reality of witches is so pertinent that not even a single individual in the entire study area, denied their existence. It is widely held that witches control evil supernatural forces by their craft to seek assistance in their deleterious doings. Usually, spells and evil-eye are the most commonly perceived modes of operation, however other methods like inscription of characters, immolation, piercing of needles on mud images, and divination are also believed to be employed for malevolent usages. They are also alleged of performing conjuring activities for gaining power from malevolent spirits for harming people. This perceived symbiotic relationship with evil supremacies, scares people and therefore it is widely suggested in the community to maintain safe distance from witches.

Just as perceived reality concerning existence of witches, tribals also ardently believe in their deleterious powers. It is widely faithed that they can cause an array of unsolicited events, ranging from pregnancy termination, sterility in males/females, ill 
health of pregnant mothers, ineffectiveness of medicines, inhibition of social interaction, memory loss, and burning sensation in body parts. Apart from these, grappling through invisible forces, cursing through spells, evil eye, rendering financial loss, poisoning of body, creating strife among family members/neighbours, vituperation, inability to attract lover, are some of the other unsolicited events which can also be maneuvered by witches.

About learning the art of witchcraft, there was nobody in the entire study area who could bear testimony of having seen the witches, learn the craft. Resident tribals only speculated that necromancy, spell casting, divination, conjuring, hypnosis, incantation, evil eye, shooting invisible arrows, poisoning, and metamorphosing, were the major sub-crafts which are mastered during the process of learning witchcraft. In the course of erudition, the trainee witches learned how to kill and bring back an individual to life. During initial stages, the craft is practiced on trees. If the learner is successful in making it dry, it is considered that her learning is entering into its advance stages. Thereafter, if she is able to bring it back to its healthy state, it is perceived that the craft has been mastered, and is ready to be tested on humans.

Owing to its apparently destructive intents, fear of influences caused by witchcraft is well stamped in the minds of tribals. There were several dogmas affiliated to this fear. A few of them include the faith that - (a) whenever there is prolonged illness in family, it is very likely to be the influence of witch residing in vicinity; (b) witches do not have any special physical character, however it is possible to identify them by their uncommon magico-religious activities carried out on moonless nights; and (c) witches can hear what is being talked about them, and hence people talk about them in susurration and refrain from discussing it with strangers. Apart from these, it is also ardently believed that - (d) females are more engaged in witchcraft than men, because after marriage, due to patrilocality, woman shift to new households and for gaining control over family affairs in the new abode, they engage in practicing the craft, which otherwise does not happen in case of men; (e) witches are actively involved in necromancy, for which skull or humerus of un-married boy or girl after his/her death (locally called saadhak) is brought in use, which in return of prayers and offerings, assists in intended deleterious activities; and (f) witches are very jealous and deleterious in causing evil influences, hence it is always better to refrain from engaging in any interaction with them, or their family members.

In instances of unsolicited events which are not considered to be natural, accusations are often levelled upon neighbours or closely residing relatives. In most cases, there is some pre-existing history of animosity between the parties. It is from here that the process of social construction of witch is triggered. In most cases neighbours, relatives and acquainted people are the ones who spread this word. This defamatory narrative building plays significant role in congregating support against the perceived witch, thereby creating an atmosphere of anxiety wherein people actually start believing that the cause of unfortunate events is vested in supernatural powers controlled by those witches. The veracity of the rumoured individual of being a witch is thereafter confirmed by the local sorcerer (bhagat) or sorceress (bhagatain).

Consequently, several ex-communications and exclusions are faced by allegedly accused witches. Fellow tribals and kinsmen abstain from inviting them in occasions of birth, marriage and socio-religious events, fearing their negative influence on the auspicious occasion. They also refrain from consuming food prepared at their home and desist their children to socialize with them. In several cases, they are driven away from community settlement, and even forced to build their house outside the village vicinity. In short, there is no sympathy for witches in the tribal worldview.

Subsequently after confirmation by sorcerer (bhagat) or sorceress (bhagatain), the position of witch is similar to that of a community criminal. If the extent of damage is less, the alleged witch is forced to consume urine or excreta. Apart from coercive feeding, face is painted with lime, head is tonsured, and she is forcefully wandered around the village with garland of shoes and damaged winnowing baskets, for making residents aware about the presence of witch, in their vicinity. These humiliations also act as warning, both for the alleged witch, as well as on-lookers for desisting from such practices.

If the magnitude of loss is more, then in such instances, all of the above is followed by hunting the 
identified witch. In most instances, killing is performed during night, when the alleged witch is jolted from sleep. Also, since the witch is believed to be armed with supernatural powers, the entire community lends support in the act. The name of fellow tribals uttered during the course of flogging and thrashing are also considered as partners in crime, and subjected to similar terminal treatment. This public action of lynching is considered to be an act of social cleansing carried out for public welfare, and hence there is no remorse about killing their own community mate. This rationality also delivers the morality for accepting witch-hunting as a justified act within the community.

In the process of witch-hunting, the conceptualization of 'victim' and 'victimizer' is quite antagonistic. For resident tribals, one who harms the community (i.e. the witch) is viewed as victimizer, and people who suffer the brunt, are perceived as victim. Contrastingly for outsiders, the witch who is ousted or killed is seen as victim, and people who are involved in branding and killing the alleged witch, are perceived as victimizers. This stark difference was also prominently noted in the study area.

\subsection{Reasons for Rampant Protuberance of Witchcraft and Witch-Hunting}

There are several factors which directly, or indirectly contribute in the sustained existence of witchhunting in the study area. Amongst them - lack of education, unmoving faith in superstitions, lack of critical thinking, village level animosity, dearth of basic health care facilities, culturally disconnected awareness schemes, sparseness of political will, absence of rehabilitation policy, deficiency in accountability fixation of village representatives and witch-doctors, and ignorance about prevailing laws - are the prominent ones. Apart from these - dearth of clarity in defining witchcraft, low quantum of punishment and piecemeal nature of Jharkhand Anti-Witch Hunting Act, combined with absence of national legislation, acquittal of culprits on evidence deficiency, under reporting of cases, lack of media attention, police apathy, poor law enforcement, non-functional fast track courts, provoking television serials, paltry funding for civil society organizations - are the other crucial factors which contribute towards sustained presence of witchhunting.
In nutshell, witchcraft finds its expression in customs and traditions of tribals, where they have deeprooted belief that it has existed since times immemorial, and shall continue to exist for ever. This faith is so embedded through socialization and upbringing, that it sharply digresses from scientifically tempered understanding of reality, making people ardently believe that anything unsolicited happening around them, is due to the considered intervention of evil spirits. By this witchcraft allegations become a way of adapting with vulnerabilities of human existence, and crediting it to local actors is the only way out in such situations (Sundar, 2001), which ultimately leads to finding of scapegoats and initiation of witch-hunting. By evaluating reasons for these uncertainties, it comes out evident that poor educational facilities, accompanied with debauched condition of healthcare amenities and stressful economic conditions, are the prime proliferators of witch-hunting.

\subsection{Interventions in Existence for Combating Witchcraft and Witch-Hunting}

There are several authoritative and judicial instruments for up-keeping the standards of human rights at par with global standards, and contending witchcraft related violence in the country. Amongst them, the prominent international instruments include Convention on the Elimination of All Forms of Discrimination Against Women (CEDAW) 1979, United Nations Declaration on the Rights of Indigenous Peoples (UNDRIP) 2007, Convention Against Torture and Other Cruel, Inhuman or Degrading Treatment or Punishment (CAT) 1984, International Covenant on Civil and Political Rights (ICCPR) 1966, International Covenant on Economic, Social and Cultural Rights (ICESCR) 1966, and Universal Declaration of Human Rights (UDHR) 1948.

Apart from international legislations, the national instruments, directly or indirectly aiming at preventing witchcraft violence, comprises of several articles of Indian Constitution, relevant sections and clauses of Indian Penal Code (IPC) 1860, Drugs and Magic Remedies (Objectionable Advertisements) Act 1954, Scheduled Castes and Scheduled Tribes (Prevention of Atrocities) Act 1989, and Protection of Human Rights Act, 1993. However, till date a national legislation on witch-hunting is still awaited. Apart from international and national commandments, there is a 
state legislation titled Prevention of Witch-Hunting (Dayan Pratha) Act, 2001 in the province of Jharkhand, which exclusively deals with witch-hunting related cases in the study area and prescribes for punishment in instances relating to such crimes.

Policy interventions for combating witchhunting were found to be very scanty in the study area. Examination of local newspapers revealed that witchhunting cases were well covered as news-items, but advisory advertisements defying such practices were barely issued by government. Regarding usage of radio, once there was a month-long drive in one of the FM radio stations against witch-hunting. However, after that, nothing was heard over the radio in this regard. The same is the case with television with no informatory advertisements being broadcasted in any of the national or regional channels. Considering the increasing instances of witch-killings, the Law Department of Government of Jharkhand, in 2016, notified the establishment of fast-track courts in Ranchi, Chaibasa, Khunti, Palamu and Simdega districts of the state, to ensure speedy trial of cases exclusively related to witchcraft violence. However, requisite man power and infrastructural resources were still awaited to be put in place for disposal of existing and emanating cases.

The Government launched a toll-free number (Women Helpline - 1091), and a mobile based application (SHAKTI) for registering issues relating to female concerns, including witch-hunting. However, there was no awareness about their existence in the study area. The Jharkhand State Women Commission in 2017, announced conducting of survey in all the villages of Jharkhand for identifying vulnerable women, likely to be labelled as witches. However, till date nothing has been initiated in that front as well. The only wing which appears to be functional at the grassroot level, are the NGOs involved in this. Only a few agencies like Sanskriti, Bhavishya Kiran, Rural Litigation and Entitlement Kendra, Free Legal Aid Committee (FLAC) and ASHA, were operational for the cause. However, due to limited outreach and fund crunch, their role also seizes to make a larger impact.

\section{THE WAY FORWARD}

Research in the study area affirms that women are overwhelmingly targeted in cases of witch-hunting. They are made scapegoats in instances of illness and conflict between families or extended families. In fact, it acts as a means through which conflicts are managed and losses are rationalized, in the community. The commonalities which emerge in all these instances include - poverty, lack of basic health care facilities, ignorance, non-rationality, socio-religious practices lacking scientific standing, and animosity with neighbours. However, given the high level of materialistic and economic deprivation in the area, it would be inappropriate to write off the entire culpability upon debilitated tribals for their lack of rationality, belief in superstition and gendered practice of witchhunting, as they do not opt for deprivation, rather suffer the consequences of it. It signals toward the negligence and apathy towards the community, and thus there is need to ponder upon the underlying causes that need amelioration. This calls for addressing the underpinning causes and conditions by adopting a holistic approach which guarantees prevention, prosecution, redressal and reparation. For ensuring this, role of education, law and public policy, are very pertinent (Alam \& Raj, 2018).

\subsection{Role of Education}

If analyzed critically, it comes out evidently that the prime reasons leading to faith in witchcraft and subsequent deleterious actions, are largely rooted in superstitious institutional practices, economic deprivation and healthcare concerns. All these factors intersect in a multi-dimensional manner causing augmentation of witchcraft related delinquencies. These culpable agents can be mitigated with the help of measures, amongst which betterment of economic condition coupled with enhanced health care facilities, inculcation of scientific temper, and adoption of rationalistic institutional practices, are of paramount significance. These curative measures can be realized by inducing education as the pivotal resolution.

In instances of witch-hunting, it is widely presumed that the witches evoke supernatural powers to cause harmful events. If pondered carefully, it comes out evidently that majority of these unsolicited events are directly, or indirectly, allied to pitiable financial conditions. Due to deficiency of monetary resources, proper reparative measures for averting the exact cause of the problem, cannot be availed (Atalay, 2015). Resultantly, the liability for everything bad is transcribed upon witches. By promoting education economic opportunities including securing of sustained 
livelihood options, enhancement of career opportunities, augmentation of productivity, and promotion of entrepreneurial and technological advancements, can be ensured. Additionally, it can also bring about social change by altering the existing socioeconomic power dynamics, wherein the alleged witches are less powerful than the people alleging them as culprits. Thus, by fostering education, negative economic circumstances accountable for bewitchment and witch-hunting can be countered efficiently, leading to weathering away of such practices.

Similarly, communities which are infamous for witch-hunting have certain common features. Amongst them - unmoving faith in existence of witches, conferment of accountability of unsolicited happenings on supernatural powers, unmitigated trust on witchdoctors and their treatment, and culturally induced miseducation which inculcates rationality and morality for accepting lynching as a justified act within the community, are quite universal (Kumari \& Alam, 2017). All these postulates are not in conformity with the basics of scientific temper and logical reasoning. With integration of critical thinking and rationality inculcated through education, diversion of faith from irrational reasoning to rationally viable causes of unsolicited events, can be ensured. Resultantly, gratuitous violence based on fictitious and un-scientific reasonings, can be deterred significantly.

Summarily speaking, education, comprising of knowledge, skills and attitude - aids in opening inward flow of ideas using critical reflection to evaluate ideas, problems and policies, that pave the path for common good of individuals as well as society. Furthermore, education conveyed through critical pedagogical mode, can lead to inculcation of critical consciousness, encouraging reasoning, questioning (Freire, 1970); and eliminating prejudices and blindfold conformity. It also supports in fostering informed choices, empowering financially, discarding health oblivions, and inducing institutional practices which are in congruence with scientific rationality. All these competences bestow education to thrive as a powerful agent of social change, and combat agents behind the sustained existence of witchcraft beliefs and witch-hunting, which are largely grounded on blaming, alleging and scapegoating. Although, substantial economic and sustained visionary efforts are required at the ground level for ensuring education to reach to those at the margin, but once achieved, it can lead to departure of such beliefs and culturally induced notions.

\subsection{Legal Recuperations}

Based on the identified reasons for sustained existence of witch-hunting in the region, it can be convincingly put forth that - the presumption behind devising of anti-witchcraft law of Jharkhand, is somewhat incongruous. It is merely an impeding mechanism and not a full proof response to the complications originating due to evil practices, unreasonableness and superstitions. It does not take into account - (a) the convictions of people, (b) the conditions under which such practices flourish, (c) the mode of reporting of cases, (d) the investigation carried after reporting, and (e) the emergent needs of victims. Due to these, it cannot end superstition, inject scientific rationality, or provide redressal to victims. Also, there is considerable gap between what the law aims to achieve, and how it is actually provisioned and thereafter executed.

First of all, the religio-cultural practices of tribals frequently involve performing of visibly similar rites and rituals, as followed in witchcraft, or opted during combating of witchcraft influences. These are very often misconstrued as witchcraft practices. Thus, what all activities and convictions are covered under the ambit of witchcraft, needs to be clearly defined in the Anti Witch Hunting Act. This dearth of conceptual clarity often leads to relatively less informed law enforcement, judgement and policy formulations. Secondly, the quantum of punishment awarded in the Act, in terms of imprisonment tenure and imposed financial penalty, if found guilty, is quite paltry. It fails to create fear and deterrence in society about the crime, and hence, a quantum increase in the prescribed punishment is solicited.

Alongside these, the criminal justice system is accountable for prosecuting the wrongdoers. It necessitates registering of accurate complaints, followed by investigation with due diligence, and then prosecution. However, in instances of witchcraft accusations, FIRs are not registered at the time of bewitchment. Police often reckon it as matter of internal strife of minuscule magnitude, and therefore desist from initiating any reparative measures. Also, cases are registered only when nature of assault involves extreme cruelty and degradation such as - physical assault, naked 
parading, tonsuring, forced consuming of excreta or killing. If the victims or their family members, approach the police without occurrence of such grave physical violence, cases are usually not registered. This is a major loop hole, which requires attention and attitudinal moderation.

Consequent upon registering of case, the antiwitch hunting law has to be invariably invoked with other provisions of IPC, indicating that the special law legislated for the purpose - is insufficient in circumscribing all forms of violence in the committed crime. Due to this, many a times, such performances tend to get booked as trivial offences. This gap needs to be addressed. Also, the nature of violence committed during witch-hunting, does not signify the mere desire to eliminate the alleged witch. There is gendered and sexual violence involved in the act, such as forced disrobing, tonsuring and naked parading, carried with the intent of degrading, stigmatizing and dehumanizing the identified witch, for which there is no penal redressal commensurate with the nature of inflicted injury. The anti-witch hunting act needs to recognize, name and accommodate commensurate redressal for such forms of degrading violence.

While legislative reforms are necessary, its impact is greatly diminished by indifferent and dispirited implementation. From failure in registering cases, taking preventive action, to poor investigation and prosecution, all such acts of omission, undermine the law. There is a pressing need to address these gaps by sensitizing the agencies working within the criminal justice system. Also, there is need for the judiciary to specifically send directions to concerned agencies and individuals, along with their judgments, so that steps toward ensuring accountability for their lapses, are inevitably taken.

Another major concern, which is usually sidelined in the entire process of justice delivery, is the lack of accountability fixation. Usually in instances of witchhunting, concomitant violence cannot thrive without consent of traditional heads and elected panchayat representatives, who despite being aware of local dynamics, do not alert local law enforcing agencies on time. Also, witch-doctors, who actually play the protagonist in identifying witches are equally accountable for instigating such practices. Their abetment in such vices are often neglected in court proceedings. This necessitates fixation of accountability and punishment, while adjudication of such cases in the court of law.

Alongside these loopholes, in view of the growing number of cases of witchcraft related violence in Jharkhand, the state government notified for establishment of fast-track courts for ensuring speedy trial and disposal of such cases. However, due to executive sluggishness, requisite man power and infrastructural resources have not yet been put in place. This needs to be taken up on priority. Also, till date, there is no national legislation for preventing witch hunting in India. Due to its non-existence, the state law fails to effectively combat witch-hunting, in want of the much-needed legal backing administered by a national legislation. This void requires immediate attention. Parallelly, another crucial hiccup identified in the study area was the - prevailing ignorance about the very existence of an act legislated for thwarting witchcraft related crimes. Resident tribals were ignorant that their custom of eliminating the witch is a punishable offence, that too cognizable and non-bailable. This ardently calls for promoting legal awareness among the tribals.

\subsection{Ameliorating Public Policy Initiatives}

In the study area, it came out conspicuously that most cases of witchcraft violence fail to reach police stations or courts. Even if taken, a substantial number are dismissed due to factors such as lack of proper investigation, absence of witnesses, minor punishment to perpetrators, or 'compromise' between victims and perpetrators. Due to these, the state witch-hunting law is unable to achieve its desired purpose. Keeping these in mind, a more social and reformative approach for subscribers of this belief system, along with addressing underlying causes, is solicited for combating this menace, rather than being strictly penal.

First and foremost, is the acute shortage of healthcare facilities. Due to abysmal condition of trained medical personnel, infrastructure crunch, affordability issues, and accessibility concerns, resident tribals are forced to rely on un-trained medical personnel (i.e. bhagats and bhagatains), who eventually, in most cases, fleece them. The grimmer side pertains to cases of failure in treatment wherein the blame of hindering the curing process is veiled upon witches. Such conditions of deprivation, indicate 
indifference towards the prevailing disparities and failure in governance. This calls for urgent structural transformation ensuring availability, accessibility and affordability of healthcare facilities. Secondly, due to deficiency of monetary resources, corrective measures like treatment in hospital for ill health, proper irrigation and manuring of crops, availing service of veterinary doctors for cattle, or other reparative measures for averting the exact cause of problem, cannot be availed. Resultantly, liability for everything bad is transcribed upon witches. Thus, addressing impoverishment, through generation of employment opportunities, is another major solicitation for contending witchcraft practices and hunting.

Adding to sorry state of affairs is the minimalistic coverage of news relating to witch-hunting and their follow-up action, by print and electronic media, especially national level agencies. Due to this, it fails to draw larger public attention, and resultantly, the accountable state actors (i.e. police and government agencies) treat it just like 'any other case of murder'. Exclusive and detailed coverage by media houses can surely assist in betterment of this depraved condition. Another crucial moderation imperative at this front, is the change in methodology of registering the case count. Currently, data relating to witchcraft related crimes in India, is aggregated by National Crime Records Bureau. It considers only the number of executions which have taken place on alleged charges of practicing witchcraft. However, instances involving gross desecration of human rights such as physical assault, naked parading, tonsuring, forced consuming of excreta etc., in which the victims were either spared or somehow managed to survive, are not covered in this counting. This underreporting belittles the real magnitude, and hence the currently followed methodology of capturing the number of cases solicits transformation.

Another recent development has been the surge in television shows aired over popular hindi entertainment channels portraying contents relating to magic, superstitions and witchcraft. Such contents reinforce faith of tribals in existence of witches and their supernatural powers. Due to this, a genre meant for entertainment of people, has emerged as a contributor in pulling back the society. This needs to be monitored and wherever required, aptly censored contemplating its larger societal impact. Additionally, another glaring concern is that two decades have passed since establishment of Jharkhand, but not even a single discussion has ever taken place in the legislative assembly of state for thwarting witchcraft related crimes, especially when the state out-ranks all other states in number of witch-hunting cases. This reflects the lackadaisical approach of political parties and elected legislators, and implores for remedial measures through moderation of existing law, ameliorating causative concerns, and ensuring accountability for acts of omission in delivery of basic needs and services, through the executive machinery.

Alongside these, there are several exclusions which are faced by alleged witches. Many survive the stigma and violence, and sustain to live with devastating consequences such as loss of home, livelihood, temporary or permanent displacement, and breakdown of family and societal relationships. However, to counter this situation of isolation, fear and impoverishment - there is no policy in the state. Measures for rehabilitation, strategy for providing compensation, legal aid, protective shelters, medical assistance, food security, re-integration of victim with families, and above all, authoritative assurance about non-recurrence of violence - are unavailable. These deficiencies, drastically inhibit recuperation of victims affected due to witchcraft stigmatization, and hence calls for immediate attention.

\section{CONCLUSION}

If pondered and analyzed critically, it comes out evidently that the prime causes leading to faith in witchcraft and subsequent deleterious actions, i.e. witch-hunting, are largely entrenched in superstitious institutional practices, economic deprivation and healthcare concerns. All these factors intersect in multidimensional manner (Crenshaw, 1991), causing augmentation of witchcraft related delinquencies in the area. These causative agents can be mitigated with the help of measures, amongst which - accountable administration, accessibility to healthcare facilities, responsive law enforcement, and efficient judicial system, are pivotal for ensuring material transformation. However, for levelling socio-economic inequalities, and transcending long held convictions, change must emanate from within the community. For this, education alone can help in desisting superstitious institutional practices, averting blindfold conformity, promoting community dialogue, engaging in remedial practices, improving livelihood support, and fostering economic 
empowerment. Cumulatively, all these can heal and rebuild the lives and families broken by such gratuitous

\section{REFERENCES}

1) Alam, S., \& Raj, A. (2017). The Academic Journey of Witchcraft Studies in India. Man in India, 97(21), pp. 123-138.

2) Alam, S., \& Raj, A. (2018). Witchcraft and Witch Hunting in India : An Assessment. National Convention on Emerging Challenges of Violence Against Women, pp. 21-25.

3) Allen, T., \& Reid, K. (2015). Justice at the Margins: Witches, Poisoners, and Social Accountability in Northern Uganda. Medical Anthropology, 34(2), pp. $110 . \quad$ DOI: 10.1080/01459740.2014.936060

4) Amnesty International (2010). Hundreds accused of 'witchcraft' persecuted in Gambia. Accessed on 28th May 2018 from https://www.amnesty.org/en/latest/news/2009/03/ hundreds-accused-039witchcraft039-persecutedgambia-20090318

5) Atalay, R. (2015). The education and the human capital to get rid of the middle-income trap and to provide the economic development. Procedia Social and Behavioral Sciences, 174 (2015), pp. 973. DOI : 10.1016/j.sbspro.2015.01.720

6) Behringer, W. (1999). Climatic change and witchhunting: the impact of the Little Ice Age on mentalities. Climatic Change, 43(1), 335-351.

7) Bosker, B. (2020). Why Witchcraft is on the Rise. Accessed on 15th August 2020 from www.theatlantic.com/magazine/archive/2020/03/ witchcraft-juliet-diaz/605518

8) Crenshaw, K. (1991). Mapping the Margins: Intersectionality, Identity Politics, and Violence against Women of Color. Stanford Law Review, 43(6), pp. 1241-1299.

9) Dilts, M. R. (2015). Power in the Name: The Origin and Meaning of the Word 'Witch'. Retrieved on 14th September 2020 from https://www.academia.edu/12416396/Power_in_t he Name The Origin and Meaning of the Wo rd_Witch_ victimization, and also contend faith in existence of witches, their perceived craft and witch-hunting.

10) Frazer, J.G. (1998). The Golden Bough: A Study in Magic and Religion. Oxford World's Classics, Oxford Publications, p.27.

11) Frazer, J.G. (2013). Aftermath: A Supplement to The Golden Bough. Cambridge University Press, p.11.

12) Freire, P. (1970). Pedagogy of the Oppressed. Penguin Books, pp. 87.

13) Goodare, J. (2016). The European Witch-Hunt. Routledge.

14) Hutton, R. (2017). The Witch: A History of Fear from Ancient Times to the Present. Yale University Press.

15) Kingsley, N.O., \& Clement, I. O. (2014). Religion and Human Rights Violation in History: The Women and Witch-Hunts in Medieval Europe. Journal of Scientific Research \& Reports, 3(24), pp. 3045-3067.

16) Kumari, M. \& Alam, S. (2017).

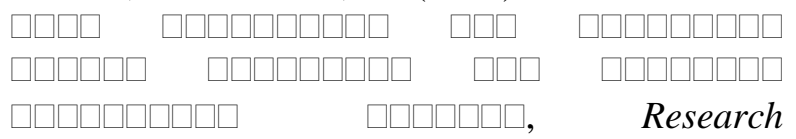

Reinforcement, 5(1), pp. 118-126.

17) Levack, B. P. (2013). The Oxford handbook of witchcraft in early modern Europe and colonial America. Oxford University Press.

18) Mabefam, M., \& Appau, S. (2020). Witchcraft Accusations and the Social Exclusion of the Elderly in Northern Ghana: Understanding How Cultural Discourses and Practices Affect the Wellbeing of the Elderly, In Measuring, Understanding and Improving Wellbeing Among Older People (Ed.), Palgrave Macmillan, Singapore, pp. 187-209.

19) Malinowski, B.K. (1944). A Scientific Theory of Culture and Others Essays. University of North Carolina Press, pp. 99.

20) Mallick, A. (2008). Witch-hunting in 1857. Economic and political Weekly, pp.118-119. 
21) Mehra, M., \& Agrawal, A. (2016). Witch-Hunting in India? Do we need special laws?. Economic and Political Weekly, Special Article, 51(13).

22) NCRB. (2018). Crime in India - 2018. National Criminal Records Bureau, Ministry of Home Affairs. https://ncrb.gov.in/en/crime-india-2018-0

23) Oliver, D.L. (1989). Oceania: The Native Cultures of Australia and the Pacific Islands, Vol. 1, University of Hawaii Press, pp. 491.

24) Purohit, K. (2020). What's to blame for Jharkhand's 'witch-hunting' problem? Poor healthcare and illiteracy. Accessed on 28th May 2020 from https://scroll.in/article/955045/whatsto-blame-for-jharkhands-witch-hunting-problempoor-healthcare-and-illiteracy

25) Saletore, R. N. (1981). Indian Witchcraft. Abhinav Publications, New Delhi, pp. 1-28.

26) Singh, R.K. (2011). Witch-Hunting: Alive and Kicking. Women's Link, 17 (1), pp. 16-21.

27) Singh. S.S. (2016). The 'witches' of Jharkhand. Accessed on $31^{\text {st }}$ January 2020 from https://www.thehindu.com/news/national/The\%E2\%80\%98witches\%E2\%80\%99-ofJharkhand/article16933528.ece

28) Srivastava, A. (2015). Over 2000 women killed in India for practicing 'black magic' in 14 years. India Today. Accessed on 15th August 2020 from http://indiatoday.intoday.in/story/over-2000women-killed-in-india-for-practicing-blackmagic-in-14-years/1/696147.html

29) Stewart, P.J., \& Strathern, A. (2004). Witchcraft, Sorcery, Rumours and Gossip. Cambridge University Press, pp. 100.

30) Summers, M. (2000). Witchcraft and Black Magic. Dover Publications, New York (USA), pp. 191.

31) Sundar, N. (2001). Divining Evil: The State and Witchcraft in Bastar. Gender Technology and Development, 5(3), pp. 425. 